\title{
ACHIEVING Graduate AtTRIBUTES THROUGH ProjeCt-BASEd LEARNING
}

\author{
Nancy Nelson \\ Conestoga College Institute of Technology and Advanced Learning \\ nnelson@conestogac.on.ca
}

\begin{abstract}
Projects are an ideal way to prepare students for the practice of professional engineering and to allow faculty to assess graduate attributes. Until now, the assessment of engineering knowledge has been sufficient for determining qualification for professional status, but recent changes now require consideration of engineering practice as well. Unfortunately many projects do not account for these additional competencies. This paper presents a method of mapping project deliverables to graduate attributes that ensures both technical relevance and coverage, and breadth of competencies.
\end{abstract}

Keywords: project-based learning, graduate attributes, engagement, project deliverables, curriculum mapping.

\section{INTRODUCTION}

Engineers Canada, the national organization of the provincial and territorial associations that regulate the practice of engineering in Canada, recently expanded the requirements for accrediting engineering programs to include graduate attributes. Accreditation review teams are requesting clear, detailed and objective tracking of these attributes. Academic institutions are introducing projects as one way to demonstrate that their graduates are both competent in engineering and understand the effects of engineering on society. This paper describes a process that maps project deliverables to graduate attributes, ensuring that projects have both technical relevance and coverage, and breadth of competencies.

\section{BACKGROUND}

Engineers Canada, defines the practice of professional engineering as "any act of planning, designing, composing, evaluating, advising, reporting, directing or supervising, or managing any of the foregoing, that requires the application of engineering principles, and that concerns the safeguarding of life, health, property, economic interests, the public welfare or the environment."[4] Accredited engineering programs have always had to demonstrate that their curriculum provides "a foundation in mathematics and natural sciences, a broad preparation in engineering sciences and engineering design, and an exposure to non-technical subjects that supplement the technical aspects of the curriculum."[2] As of June 2015, each accredited engineering program in Canada has to demonstrate that their graduates possess a set of attributes that ensure an "understanding of the effects of engineering on society" as well as "competence in engineering".[3]

\subsection{Graduate Attributes}

Twelve graduate attributes, as defined by Engineering Canada, have been established to help assure that graduating engineers are prepared to practice professional engineering in this country. Engineering programs have always ensured that graduates possess the more traditional attributes of (1) a knowledge base for engineering, (2) problem analysis, (3) investigation, (4) design, and (5) use of engineering tools. Together these ensure competency in engineering.

However, a 2010 study of over 5,500 engineering students and recent graduates found that many of them did not feel that they had a real understanding of what it means to be an engineer, or what their professional careers would actually involve.[1] These students identified three main areas they felt that they were lacking: (i) communication, interpersonal and professional skills, (ii) teamwork, and (iii) the ability to solve the more ambiguous, complex, and multi-faceted problems presented in the workplace.

To ensure that engineering students who graduate from accredited programs are prepared to practice professional engineering, seven additional graduate attributes were specified including: (6) individual and team work, (7) communication skills, (8) professionalism, (9) impact of engineering on society and the environment, (10) ethics and equality, (11) economics and project management, and (12) life-long learning. 


\subsection{Project-Based Learning}

Historically, projects have played a very minor role in engineering programs. Curriculum essentially focused on the mathematics, natural sciences, engineering fundamentals, and specialized engineering knowledge appropriate for the discipline. Engineering design experience came solely in the form of a culminating or capstone project where the graduating student focused on solving a technical problem. As part of this course, students were required to present their work both orally and as a formal document. There was little, if any, emphasis beyond the traditional graduate attributes.

In order to graduate students who are better prepared to practice professional engineering, many engineering programs have recently added elements of project-based learning to their curriculum.

Project-Based Learning (PBL) has myriad definitions and is implemented in many different forms. There are however four main characteristics that differentiate a project from a conventional learning activity.[2] First there must be significant content where students apply and integrate key knowledge and skills. Secondly, there must be an appropriate level of rigour and complexity. A project must be open-ended, allowing students to develop more than one reasonable answer, and providing them with autonomy and choice as they work toward a solution. Finally, a project must be explorative where students are motivated to identify, research, and learn concepts and skills required to reach a solution.

In engineering education PBL is typically implemented using one of three models (see Figure 1):

i) project-centric - projects form the central and dominant component of the curriculum; the subject material studied is determined by the demands of the project[6] and emphasis is placed on process

ii) project-supported - projects focus on application of material studied in one or more separate courses delivered in a particular academic term

iii) project-spline - projects focus on the acquisition and development of project-related knowledge and skills and is delivered as a separate project course
The value of PBL is shown in the results of a 2010 student engagement survey of more than 42,000 high school students.[8] Almost $60 \%$ of learners indicated that they are engaged when doing projects compared to only $25 \%$ who are engaged when listening to a lecture.

By actively engaging students with authentic and relevant projects, it is possible to identify and track key indicators of graduate attributes.

\section{PROCESS}

Since its first offering in 2004, the Electronic Systems Engineering (ESE) program (and its predecessor applied technology program - Integrated Telecommunication and Computer Technologies) at Conestoga College Institute of Technology and Advanced Learning has used a projectcentric model of PBL with projects designed to cross course and discipline boundaries.[5] Students complete two or three authentic, level-appropriate projects each academic term in addition to a capstone project. This type of learning forces students to constantly think and work like engineers, using standard techniques and practices for solving technical problems. It makes students highly employable when seeking co-op positions and establishing careers. Feedback from employers indicates students and graduates have the technical knowledge and skills, the ability to actively contribute to engineering teams and their on-going projects, and an awareness of the business needs necessary to make a product viable in today's competitive marketplace.

In 2013, as part of the preparation for an accreditation review by the Canadian Engineering Accreditation Board (CEAB), the ESE program began a comprehensive review of each project to ensure compliance with the graduate attributes requirement. Each project was measured against three criteria:

i) adherence to PBL characteristics

ii) technical relevance

iii) breadth of competencies related to the practice of professional engineering

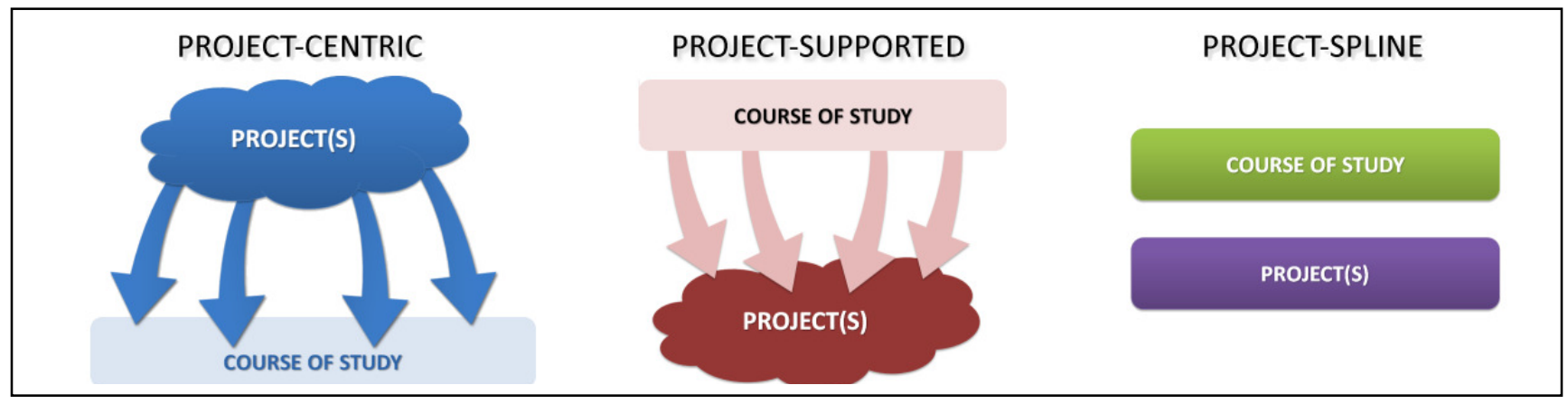

Figure 1: $\mathrm{PBL}$ in engineering 


\subsection{Adherence to PBL Characteristics}

Before starting the review it was important to have a clear picture of how projects are to be configured. Figure 2 shows that the foundation of each ESE project is based on at least one of the three pillars of engineering: (i) design, (ii) problem analysis, or (iii) investigation, as governed by the overarching knowledge base. This is supported by the use of applicable engineering tools and methods. The project must follow proper project management techniques and apply appropriate business and economic principles. In addition, elements of professional engineering practice such as team work, effective communication of ideas and findings, and adherence to professional, ethical, and legal responsibilities must be incorporated where appropriate.

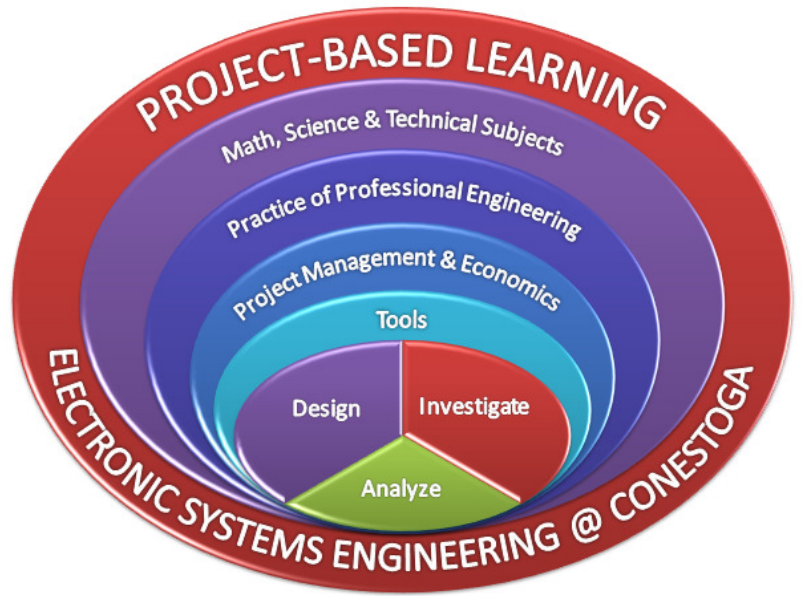

Figure 2: PBL model for ESE program

The mathematics, natural science and engineering science content of each project is then mapped to the curricular objectives for the academic term. The project must integrate a significant number of new concepts and skills to be learned with the students' prior knowledge.

The next stage is to evaluate the project's problem statement or driving question against the following criteria:

i) provides clear direction for the students - helps steer students in the desired direction while still allowing them some freedom of choice

ii) encapsulates the project idea within the context of the curriculum and is both authentic and realizable

iii) forces students to explore and learn key knowledge, skills, and processes in order to reach a viable solution

iv) poses a level-appropriate challenge to the students A well-defined project enables all students, even those with different abilities, to be successful while still demonstrating the required level of mastery.

\subsection{Technical Relevance}

It is important that every project demonstrate technical relevance. Authentic student engagement, as defined by Schlechty, occurs when students are challenged by work that has "clear meaning and relatively immediate value".[7] Students actively participate in projects that are perceived to be technically relevant.

A yearly scan of national and local industry trends provides the program with up-to-date data regarding the employment and economic impact of the electronics, software, and telecommunications sectors. In addition, ESE's Program Advisory Committee (PAC) provides semi-annual reports on the state of the electronics industry and the technological implications of any changes or trends. This data is used to ensure that all projects are technically relevant.

\subsection{Professional Engineering Competencies}

The final stage in the review of a project is to ensure that elements of professional engineering practice such as team work, effective communication of ideas and findings, and adherence to professional, ethical, and legal responsibilities are incorporated where appropriate.

A review of the project's deliverables identifies precisely which professional engineering practice competencies are currently evaluated. Mapping each deliverable to a graduate attribute key indicators table, helps highlight where, and to what level of mastery, professional practice competencies are assessed.

As maps are completed for each project in the ESE program it becomes possible to identify and correct gaps and deficiencies in demonstrating compliance with each of the professional engineering graduate attributes.

\section{SAMPLE REVIEW}

The first project reviewed was a Field Meter Project (FMP). The original task was two-fold: (i) design, program, and test a microcontroller-based magnetic field measurement device, and (ii) design, layout, fabricate and test an external printed circuit board (PCB) based sevensegment display for the meter.

\subsection{FMP Review}

A mapping of the FMP outcomes to the mathematics, natural science, and engineering science curricular objectives showed significant coverage of the concepts and skills to be learned. It also built on the students' prior knowledge and skills acquired during prior projects.

An examination of the FMP's problem statement revealed that over the years, it had evolved from an open- 
ended task to one that was quite prescriptive. While the context remained authentic, the complexity had increased such that it was very challenging for many students.

The potential harmful effects of electro-magnetic fields (EMF) on human physiology remains a hot topic in the media. With more and more wearable consumer electronic devices hitting the market every day, the FMP still remains technically relevant.

An examination of the FMP deliverables identified a clear focus on the technical design and implementation aspects of the project. Other than a formal report that documented the design process, there were no other professional engineering competencies assessed. Clearly the outcomes of the FMP needed to be revised.

\subsection{FMP Revision}

The first stage in revising the FMP was to ensure that it adhered to the characteristics of PBL. Noting the newsworthiness of the effects of EMF on humans, the problem statement was revised to "an investigation into the effect that the magnetic field generated by common household appliances has on the human body. A studentdesigned magnetic field measuring device allows the capture of a series of $\mathrm{x}, \mathrm{y}, \mathrm{z}$ field strength readings. This data is analyzed to determine whether exposure to the electro-magnetic fields (EMFs) causes electric currents or fields in the body that are stronger than the ones produced naturally by the brain, nerves and heart".

Using this revised problem statement, Figure 3 shows the stages required to successfully complete the project.

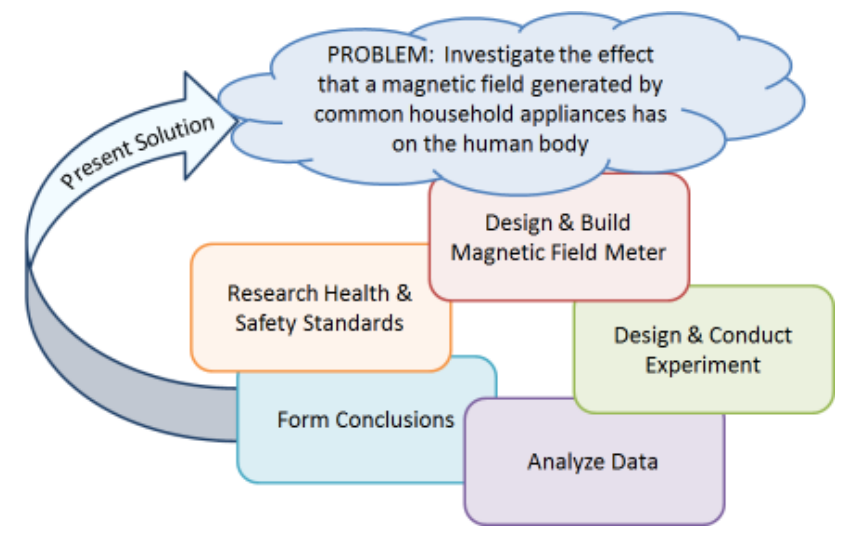

Figure 3: Stages of revised FMP

This revised problem statement was then measured against each of the four characteristics of an effective project. New project deliverables were identified and mapped to the curriculum to ensure significant coverage. This map, a portion of which is shown in Figure 4, shows that while there was significant technical coverage, the only deliverables related to engineering practice competencies were communication related. If desired, this would be the time to broaden the project deliverables.

This mapping analysis showed that the revised FMP met the characteristics of a good PBL project by (i) covering significant content, (ii) offering a levelappropriate challenge for all students, (iii) providing an open-ended challenge, and (iv) requiring students to research, design, experiment, and analyze in the process of reaching a solution.

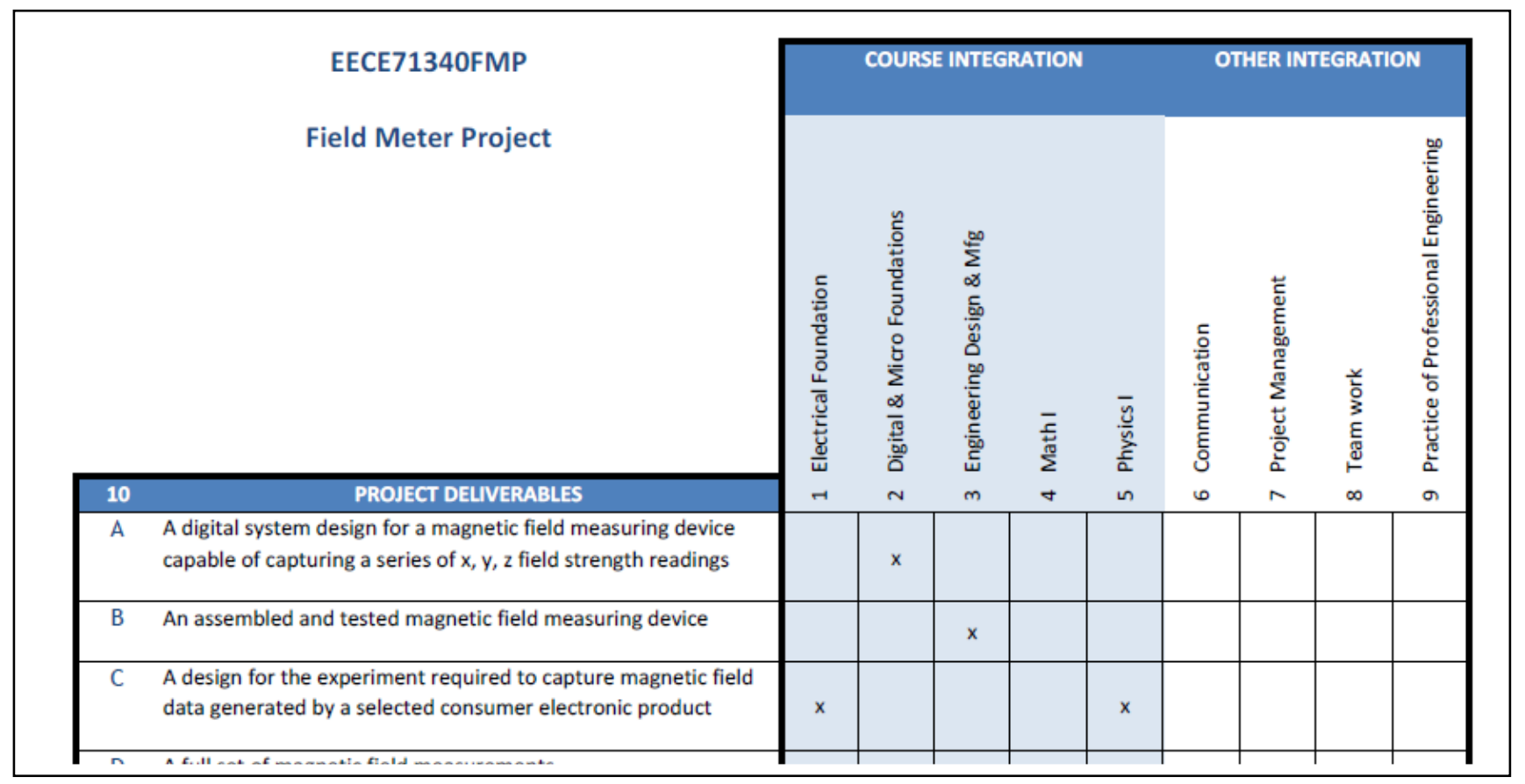

Figure 4: Mapping Deliverables to Curriculum 
The initial review of the FMP showed that it did meet the technical relevancy requirement, so no revision was required in this area.

The last phase of the review was to map each project deliverable to graduate attributes. As seen in Figure 5, each graduate attribute has a number of indicators (ex. IV1-IV3, ED1-ED2), each of which has a set of specific performance indicators. These performance indicators range from Lower Order Thinking Skills (LOTS) such as
Knowledge and Comprehension through to Higher Order Thinking Skills (HOTS) such as Integration and Evaluation. Each project deliverable was mapped to as many performance indicators as were applicable.

Data from this attribute map automatically populates a summary chart of graduate attributes (see Fig. 6). This summary chart provides a quick reference of the graduate attributes supported by the project.

\begin{tabular}{|c|c|c|c|c|c|}
\hline & & Lower Or & der & Thinking Skills & \\
\hline & Indicators & $\begin{array}{l}\text { Knowledge \& Comprehens } \\
\text { being able to recall what you lea } \\
\text { define, explain or give example } \\
\text { others }\end{array}$ & $\begin{array}{l}\text { ion } \\
\text { in and } \\
\text { es to }\end{array}$ & $\begin{array}{l}\text { Application (Making use of } \\
\text { Knowledge) } \\
\text { using information to accomplish } \\
\text { something concrete }\end{array}$ & $\begin{array}{r}\text { Analysi } \\
\text { being able to } \\
\text { collect }\end{array}$ \\
\hline & Investigation & & & & \\
\hline IV1 & $\begin{array}{l}\text { Research } \\
\text { Explores, understands, or } \\
\text { learns about a problem }\end{array}$ & $\begin{array}{l}\text {...explain a problem in their own } \\
\text { words, find information needed } \\
\text { to solve the problem, and } \\
\text { determine what they need to } \\
\text { know to solve the problem }\end{array}$ & & $\begin{array}{l}\text {...find and use information } \\
\text { needed to solve a problem from } \\
\text { textbooks, on-line resources, } \\
\text { databases, or other technical } \\
\text { documentation }\end{array}$ & $\begin{array}{l}\text {...select and } \\
\text { that is usef }\end{array}$ \\
\hline IV2 & \begin{tabular}{|l|} 
Measure \\
Determines how well a system \\
or device functions by \\
performing measurements
\end{tabular} & $\begin{array}{l}\text {..select the correct } \\
\text { measurement instrument for a } \\
\text { task and identify the protocol for } \\
\text { taking the measurement }\end{array}$ & Pro & $\begin{array}{l}\text {...take valid measurements using } \\
\text { instruments and record the data } \\
\text { ect Deliverables }\end{array}$ & $\begin{array}{l}\text { analyz } \\
\text { determ } \\
\text { functio }\end{array}$ \\
\hline IV3 & \begin{tabular}{|l|} 
Experiment \\
Plans, and conducts an \\
investigation, makes \\
observations, summarizes \\
results, and draws \\
\end{tabular} & $\begin{array}{l}\text {...plan an engineering } \\
\text { investigation identifying what } \\
\text { data needs to be collected and } \\
\text { how it is to be collected }\end{array}$ & $\mathrm{C}$ & $\begin{array}{l}. . \text { systematically conduct an } \\
\text { investigation, recording data and } \\
\text { observations }\end{array}$ & $\begin{array}{l}\text {...revi } \\
\text { obse } \\
\text { ap } \\
\text { a }\end{array}$ \\
\hline & & & & Performance Ind & tors - \\
\hline
\end{tabular}

Figure 5: Mapping deliverables to attributes

\begin{tabular}{|c|c|c|c|c|c|c|c|c|c|c|c|c|}
\hline \multicolumn{12}{|c|}{ GRADUATE ATTRIBUTES } & \multirow[b]{2}{*}{$\begin{array}{l}I=\text { Introduced } \\
D=\text { Developed } \\
A=\text { Applied }\end{array}$} \\
\hline \multirow[t]{5}{*}{ 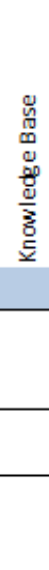 } & 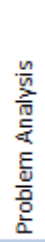 & 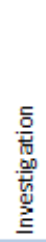 & $\frac{.50}{\bar{y}}$ & 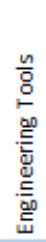 & 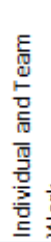 & . & 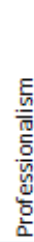 & 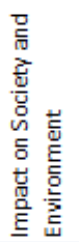 & 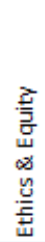 & 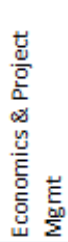 & 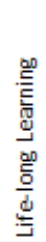 & \\
\hline & D & DA & DA & D & & t & & & & & & PROJECT DELIVERABLES \\
\hline & & D & DA & & & & & & & & & $\begin{array}{l}\text { A A digital system design for a magnetic field } \\
\text { measuring device capable of capturing a series of } x, y \text {, } \\
z \text { field strength readings }\end{array}$ \\
\hline & & & D & & & & & & & & & $\begin{array}{l}\text { B An assembled and tested magnetic field measuring } \\
\text { device }\end{array}$ \\
\hline & & $\mathrm{D}$ & & & & & & & & & & $\begin{array}{l}\text { C A design for the experiment required to capture } \\
\text { magnetic field data generated by a selected } \\
\text { consumer electronic product }\end{array}$ \\
\hline
\end{tabular}

Figure 6: Section of graduate attributes summary chart 


\begin{tabular}{|c|c|c|c|c|c|c|c|c|}
\hline \multicolumn{4}{|c|}{ Engineering Investigation } & Mastering & Competent & \multicolumn{3}{|c|}{ Emerging } \\
\hline \multicolumn{3}{|c|}{ DELIVERABLE } & & $10 \quad 9$ & 7 & 4 & 3 & \\
\hline \multirow[t]{5}{*}{ c } & \multirow{5}{*}{$\begin{array}{l}\text { A design for the experiment } \\
\text { required to capture magnetic } \\
\text { field data generated by a } \\
\text { selected consumer electronic } \\
\text { product }\end{array}$} & IV3 & Plan & $\begin{array}{l}\text { Experiment is clearly } \\
\text { and completely defined }\end{array}$ & $\begin{array}{c}\text { Experiment is only partially } \\
\text { defined }\end{array}$ & \multicolumn{3}{|c|}{ Experiment is minimally or } \\
\hline & & IV3 & Conduct Investigation & $\begin{array}{l}\text { Experimental data is } \\
\text { clearly and completely } \\
\text { documented }\end{array}$ & $\begin{array}{l}\text { Experimental data is } \\
\text { partially documented }\end{array}$ & \multicolumn{3}{|c|}{$\begin{array}{c}\text { Experimental data } \\
\text { docume }\end{array}$} \\
\hline & & IV3 & Make Observations & \begin{tabular}{|c|} 
Uses a model to \\
effectively \\
communicate \\
engineering processes \\
and systems \\
\end{tabular} & $\begin{array}{c}\text { Uses a model to adequately } \\
\text { communicate engineering } \\
\text { processes and systems }\end{array}$ & \multicolumn{2}{|c|}{$\begin{array}{c}\text { No model pre } \\
\text { inc }\end{array}$} & \\
\hline & & IV3 & Summarize Results & $\begin{array}{c}\text { Presents insightful \& } \\
\text { thorough interpretation } \\
\text { of results }\end{array}$ & $\begin{array}{l}\text { Presents thorough } \\
\text { interpretation of results }\end{array}$ & \multicolumn{2}{|l|}{ Does not $\mathrm{P}$} & \\
\hline & & IV3 & Draw Conclusions & $\begin{array}{c}\text { Conclusions are clear, } \\
\text { concise and based on } \\
\text { extensive supporting } \\
\text { evidence }\end{array}$ & $\begin{array}{c}\text { Conclusions are valid and } \\
\text { based on supporting } \\
\text { evidence }\end{array}$ & \multicolumn{2}{|l|}{ Conclu } & \\
\hline
\end{tabular}

Figure 7: Section of FMP evaluation rubric

Data from the graduate attribute map (see Fig. 5) is also used to automatically generate evaluation rubrics. A sample rubric (see Fig. 7) shows a graduated measurement scale ranging from Emerging, through Competency, to achieving Mastery. Each project deliverable corresponds to one or more rubric item and a specific graduate attribute key indicator. Together this information provides the student with a comprehensive look at how well the deliverable meets the project requirement, and which graduate attribute is being measured.

This review process was repeated for each project in the program ensuring that each met the three criteria established for a well-defined project. An analysis of the complete set of graduate attribute summary charts identified any gaps in achieving compliance with CEAB's requirement for graduate attributes. Gaps were corrected by adding appropriate deliverables to selected projects.

\section{SUMMARY}

Projects are an ideal way to help students prepare for the practice of professional engineering and to demonstrate compliance with CEAB's requirement for graduate attributes. The process described in this paper establishes that mapping project deliverables to graduate attributes ensures technical relevance and coverage, as well as breadth of competencies.

\section{References}

[1] Cynthia J.Atman, Sheri D. Sheppard, Jennifer Turns, Robin S. Adams, Lorraine N. Fleming, Reed Stevens, Ruth A. Streveler, Karl A. Smith, Ronald L. Miller, Larry J. Leifer, Ken Yasuhara, and Dennis Lund. Enabling Engineering Student Success: The Final Report for the Center for the Advancement of Engineering Education. San Rafael, CA: Morgan \& Claypool Publishers, 2010. Available as of April 26, 2014 from

http://www.engr.washington.edu/caee/final_report.html

[2] Buck Institute of Education, "Project Design Rubric", Project Based Learning. Novato, CA: Buck Institute of Education, 2013. Available as of April 26, 2014 from http://bie.org/object/document/project_design_rubric

[3] Engineers Canada, 2013 Accreditation Criteria and Procedures. Ottawa, ON: Engineers Canada, 2013. 29 pp. \{ISSN 1708-8054\}. Available as of April 26, 2014 from http://www.engineerscanada.ca/accreditation-resources

[4] Engineers Canada, Guideline on Admission to the Practice of Engineering in Canada. Ottawa, ON: Engineers Canada, 2013. 29 pp. Available as of April 26, 2014 from http://www.engineerscanada.ca/national-guidelines

[5] Monzur Kabir and Nancy Nelson, "Project-Based Curriculum Design - A Practitioner's View", in International PBL Symposium 2007 Conference Proceedings, 2007. Available as of April 8, 2014 from http://engagingourlearners.pbworks.com/w/page/56611419/ Project $\% 20$ Based\%20Learning

[6] Alistair Morgan, "Theoretical Aspects of Project-Based Learning in Higher Education", British Journal of Educational Technology, vol 14, pp. 66-78, 1983. 
Proc. 2014 Canadian Engineering Education Association (CEEA14) Conf.

[7] Phillip C. Schlechty, Working on the Work: An Action Plan for Teachers, Principals, and Superintendents. San Francisco, CA: Jossey-Bass, 2002, 160 pp. \{ISBN: 9780787961657\}

[8] Ethan Yazzie-Mintz, "Charting the Path from Engagement to Achievement: A Report on the 2009 High School Survey of Student Engagement," Center for Evaluation \& Education Policy, Indiana University, 2010, 28 pp. Available as of April 8, 2014 from http://ceep.indiana.edu/hssse/images/HSSSE_2010_Report. pdf 